\title{
Recent Examples of Bookmaking in the United States
}

\author{
STEVEN CLAY a n d D A I D A B E L
}

It seems appropriate to begin our survey with the following words by David Schoonover, Curator of Rare Books in The University of Iowa Libraries. They are taken from his article, "The University of Iowa Center for the Book," which appeared in the November 1987 issue of this journal: "It must be emphasized here that the word book in the center's title is used as a paradigm. While 'the book' as normally thought of is the core of the center's activities, the word itself is intended to cover every aspect of written or printed communication, in terms of physical development and cultural importance...consequently, where the word book is encountered in the following pages, it should be read with this broad definition in mind."

Throughout its historical development, the roles that the book has played (and the concomitant conceptions and classifications that have been applied to it, both by practitioners and others) have undergone continual revision and replacement. Often gradual, but sometimes sudden; often due to technical advances but also to shifts in the conditions of culture itself, these changes are irresistible, in any event. If this survey seems perhaps a little broad and indelicate, it may be because we have attempted to include activity which consciously situates itself at that point of changing understandings.

The notices that follow are grouped geographically as a matter of convenience. We have long had one foot in the global village, and any careful attempt to elucidate the contemporary history of the book would of necessity have to be international in scope, and interdisciplinary in approach. In the meantime, we would like to point to selected recent works, and give sketches of a few of the artists behind them. We are restricted to those presses and artists with whom we are most familiar. There are undoubtedly many others producing first-rate work 
whose absence from this listing is indicative only of our own present ignorance, and to whom we would offer our apologies.

\section{THE WEST}

The continuity of the fine press tradition in California is often noted. Whereas the activity in many other areas of the country is of relatively more recent origin, the legendary work in the pre-World War II years of the Grabhorn Press, John Henry Nash, Ward Ritchie, and the Plantin Press of Saul and Lillian Marks, among others, has lent to the region a useful sense of indigenous tradition, admirably carried forward in the succeeding generation by such printers as Lewis and Dorothy Allen, Adrian Wilson, Jack Stauffacher, and William Everson.

University-based programs in the book arts at the University of Southern California, Scripps College, the University of California at Santa Barbara and, until recently, Mills College, have stimulated a great deal of interest and attention, and encouraged many prospective book artists. Among the pertinent publications originating on the West Coast are Fine Print, the premier journal of the book arts in the U.S., now in its thirteenth year, edited by Sandra Kirschenbaum, and The Ampersand: Quarterly Journal of the Pacific Center for Book Arts edited by Alastair Johnston, both published in the Bay Area; and Abracadabra, the publication of the Alliance for Contemporary Book Arts in Los Angeles.

\section{ARIF PRESS (Berkeley, California)}

Wesley B. Tanner is certainly a prominent member of the San Francisco Bay Area community of fine publishers. Running one of what seem to be only a few real letterpress "job shops" left in the country, Wesley (in conjunction with Will Powers) was responsible until 1988 for the design and printing of Fine Print magazine, as well as numerous other publications. His Arif Press has published an unusually wide range of material from contemporary poetry (Joanne Kyger, Jack Spicer, Michael McClure and many others) to piano technique (Alexander Libermann's A Comprehensive Approach to the Piano, published in 
1984) and, most recently, back to poetry-way back, to Horace's Ars Poetica (1989) printed entirely in the original Latin.

The last couple of years has found Wesley experimenting with a printmaking technique learned from Valenti Angelo, "The Angelo Process," used to extremely good effect in Arif's Twelve Portraits (1987) by Stephen Mitchell. In 1988 he issued Vide Cor Tuum, a portfolio of lovely and subtle relief prints made using this process, published under the Jaguar Editions imprint.

\section{ARION PRESS (San Francisco, California)}

Founded by Andrew Hoyem in 1974, the Arion Press has consistently set standards, if not to say records, with the ambition and execution of its editions, from the justly-famous Moby Dick (1979) of Melville and Self-Portrait in a Convex Mirror (1984) of John Ashbery, to the recently released Ulysses (1988) of James Joyce. In this impressive edition, the text is set in Monotype in a generous 18 point Perpetua; however, since matrices were never made for the italic, all such instances were set by hand. Printed on French mouldmade paper, and illustrated with a suite of etchings by abstract expressionist painter Robert Motherwell, this very large folio volume (837 pages) is surprisingly intimate and readable, and offers an appropriate tribute to the genius of Joyce.

\section{BIELER PRESS/UNIVERSITY OF SOUTHERN CALIFORNIA FINE ARTS PRESS (Los Angeles, California)}

Gerald Lange's Bieler Press began in 1975 while he was a student at the University of Wisconsin at Madison. Since that time over forty books, pamphlets and broadsides have been produced. Primarily a literary press, Bieler emphasizes the publication of work by little known writers, and in this context has produced some real gems. Among the many such noteworthy books particular mention should be made of three: Christopher Buckley's Five Small Meditations on Summer and Birds (1984) with its covers of Richard de Bas handmade Papier A Inclusions Florales; John Gilgun's Everything That Has Been 
Shall Be Again (1981) with nine wood engravings by Michael McCurdy; and David Romtvedt's Moon (1984) illustrated by R.W. Scholes. These three books are characteristic of Bieler's output on the whole: a fine marriage of solid writing, materials of high quality, and impeccable printing.

The press moved from Wisconsin to the Twin Cities of Minnesota in 1980, and then again in 1986 to Los Angeles, when Lange was chosen to fill the position of Master Printer at the newly formed University of Southern California Fine Arts Press. The first publication to issue from this facility, which functions as a repository and a teaching laboratory as well as a publisher, is The Letter of Columbus on the Discovery of the New World (1989). It contains a facsimile of the Stephen Plannck 1493 Latin edition (including reproductions of five woodcuts), supplemented with an introductory essay, English translation, and bibliographic afterword.

\section{CHAX PRESS (Tucson, Arizona)}

Poet and printer Charles Alexander co-founded the Black Mesa Press in Madison, Wisconsin, in 1979. After his move to Tucson in 1984, Black Mesa was dissolved and Chax born. Much of Charles's work centers around a concern with the role that experimental bookmaking can play in conjunction with avantgarde writing. This is powerfully exemplified in his latest publication, Individuals (1988). Subtitled a book of twenty-four poems written individually in the fall of 1986, the texts were written in, and as, correspondence between the poets Lyn Hejinian and Kit Robinson. Each poem is printed individually on an index card sized sheet of Rives paper. Two sheets are tipped onto each fold of the accordion spine structure, and separated by a black Fabriano "mark." The unusual structure (based on a binding taught by Hedi Kyle) emphasizes and counterpoints a 
theme of division found also in the poems: what are the "parts" of a poem or a book; what are the relations between, and within, the persons?

\section{NINJA PRESS (Sherman Oaks, California)}

Carolee Campbell's Ninja Press has published four books to date, each a little more ambitious than the last. Her Mirror (1987), a single poem by Guillaume Apollinaire, printed in both French and English, stole the show at the 1987 Western Books competition in Los Angeles. Using cut and folded paper techniques, it is a three-dimensional rendition of the original, one of the pictorial or "shaped" poems that appeared in the author's Calligrammes. The current production of the Press is a lovely new edition of Thoreau's Walking (1988), published in association with the Friends of the Library of the University of California, Santa Barbara, and edited, designed, printed and bound by Carolee, based on the manuscript in the Concord Free Public Library.

\section{PARADISE PRESS (Santa Monica, California)}

Though the approaches Susan King has used have varied as her interests and the direction of her press have changed, nonetheless her books, broadsides and postcards have always been enlivening and insistent examples of an artistic spirit. Her involvement is comprehensive, as writer, designer, printer and binder; her works are technically adventuresome and conceptually sophisticated in all respects. Two recent books illustrate her equal fluency in both classic and experimental approaches: Lessonsfrom the South (published by Nexus Press in 1986) is printed offset on pages glued into a die-cut accordion binding of archival corrugated plastic; whereas Say See Bone, Lessonsfrom French (1988) is printed letterpress from monotype on handmade paper, and bound by hand in a variation of a coptic binding. Her most recent project is Home/Stead (published by the Power of Place, 1989), a commemoration of the life of Biddy 
Mason, a former slave whose philanthropic achievements in Los Angeles are the subject of a series of public art works in that city.

\section{POLTROON PRESS (Berkeley, California)}

Among the more exotic letterpress operations in the United States, mention must be made of the Poltroon Press of Berkeley, California. Co-proprietors Frances Butler and Alastair Johnston have published a sizable body of work whose content ranges from contemporary poetry by the likes of Darrell Gray, Larry Fagin and Tom Clark, through monographs on contemporary art, to Hendrik D.L. Vervliet's Cyrillic and Oriental Typography in Rome at the End of the Sixteenth Century: an Enquiry into the Late Work of Robert Granjon (1578-1590) (1981). Also of great interest are Alastair Johnston's two anecdotal bibliographies, A Bibliography of the Auerhahn Press \& Its Successor, Dave Haselwood Books (1976) and A Bibliography of the White Rabbit Press (co-published with Anacapa Books in 1985).

\section{SEA PEN PRESS AND PAPERMILL (Seattle, Washington)}

Neal Bonham and Suzanne Ferris operate the Sea Pen Press and Papermill from Seattle, Washington. Their publications of contemporary poetry are distinctive for their use of beautiful handmade papers and for the innovative binding structures often executed by Judith Johnson. The most recent example is Even Money, poems by Thomas Brush illustrated with linocuts by Suzanne Ferris, and a pictorially watermarked coverstock by Neal Bonham.

\section{W. THOMAS TAYLOR (Austin, Texas)}

A well-known antiquarian bookseller located in Austin, Texas, Taylor began his publishing program in 1976 with a book by English poet Christopher Middleton. The editorial concerns of the Press encompass literary works as well as works pertaining to the arts of the book. Titles by Bernard Shaw and John Fowles were followed in 1980 by Twenty-One Years of Bird \& Bull, a bibliography compiled by Taylor and Henry Morris, and in 
1983 by both Printer's Choice, the catalogue of an exhibit of fine printing held at the Grolier Club in New York City,

\section{DOORS OF PERCEPTION \\ ESSAYS IN BOOK TYPOGRAPHY \\ HARRY DUNCAN}

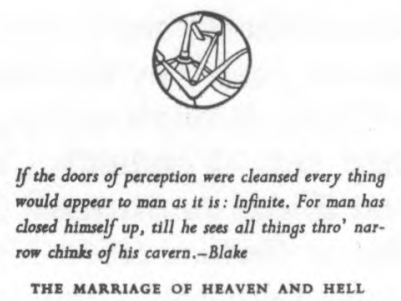

W. THOMAS TAYLOR

$A$ U TIN

${ }_{1} 983$

and Doors of Perception, a collection of important essays on typography and printing by Harry Duncan. Plans for several other projects are in place, including Joseph Blumenthal's biographical Bruce Rogers: 1870-1957. Though the Press began by commissioning all production work, facilities now exist for typecasting as well as printing, most of which is done in-house.

Tom Taylor's personal imprint The Kairos Press has published several titles, most notably The Stone Beloved (1986), containing translations by Harry Duncan of little-known poems of Dante, with seven original lithographs by Peter Nickel.

\section{TURKEY PRESS (Isla Vista, California)}

Since 1974 the Turkey Press has been publishing significant works of contemporary literature, beginning in Providence, Rhode Island, and then moving to Isla Vista, California in 1977. 
To date over forty books have been produced by Harry and Sandra Reese who do most of their own printing, typesetting, binding, design and some papermaking. Their 1986 publication of Five Meters of Poems (translated by David Guss for this first English-language edition) is exemplary of the Reeses' editorial and technical skill. The first and only book by Peruvian poet Carlos Oquendo de Amat (1905-1936), whom Mario Vargas Llosa described as "a consummate sorceror, a wizard with a word, a daring architect of images, a blazing explorer of dreams," it was written between 1923-1925 and first published in 1927. The Turkey Press edition follows the original format consisting of the eighteen typographically playful poems in a visual sequence of accordion-folded panels which unfold to five meters in length.

Harry Reese's research and experimentation in printmaking has been documented in The Sandragraph: Between Printing and Painting, published by the Arundel Press in 1987. Other recent Turkey publications have included work by Thomas Merton, James Laughlin and Michael Hannon. A partial list of other significant presses in the West would begin with: Allen Press; Arundel Press; Good Book Press; Greenwood Press; Heyeck Press; Jungle Garden Press; Kutenai Press; Lapis; Lime Kiln Press; James Linden; Meadow Press; Peter \& the Wolf; Pyracantha Press; Rebis Press; Charles Seluzicki; Scripps College Press, and Yolla Bolly Press.

\section{MIDWEST}

Although printing courses had been taught at The University of Iowa since the late 1930s, serious typographic studies began there in 1945 with the establishment of the Typographic Laboratory. Carroll Coleman, founder of the Prairie Press, was appointed as the lab's first director. He was succeeded in 1956 by Harry Duncan, whose Cummington Press had issued some of the most important books of the preceding twenty years, and who in turn passed the mantle on to Kay Amert of the Seamark Press in 1971. The felicitous coexistence on the same campus of the Typographic Laboratory and the renowned graduate-level 
Iowa Writers' Workshop has created an environment in which literally dozens of small and fine press publishing ventures have been born.

The vanguard role of lowa was demonstrated again in 1986 with the creation of The University of Iowa Center for the Book, a unique interdisciplinary program in which the book in all of its manifestations can be studied seriously.

The other centers of book arts activity in the midwest are Madison, Wisconsin; Omaha, Nebraska; and Minneapolis, Minnesota. The list of printers and book artists who have studied under master printer and papermaker Walter Hamady at Madison is extraordinary, as is his twenty-five year output at the Perishable Press. Also at Madison is the superb Silver Buckle Press collection of printing equipment.

In 1973 Harry Duncan joined the faculty of the University of Nebraska at Omaha. There he directed the publication program of Abattoir Editions and taught in the book arts program, until his retirement in 1986. The book arts program and Abattoir continue under the direction of Bonnie $\mathrm{O}^{\prime}$ Connell of the Penumbra Press, and plans are well underway for the establishment of the Nebraska Center for Book Arts.

In 1986 the Minnesota Center for Book Arts (MCBA) was established in Minneapolis. From the beginning MCBA's outlook has been international rather than regional in scope, featuring major exhibitions, most of which originate there. They also offer book arts courses for all ages, making good use of their printing, papermaking and (soon) typecasting facilities, supplemented by various other educational and curatorial programs.

\section{CUMMINGTON PRESS (Omaha, Nebraska)}

After fifty years of printing, having inspired several generations of printers and writers through his example and through teaching, Harry Duncan continues with the selfsame vigor to publish original works (usually poetry) in handsome hand printed editions, his aim being "to exceed the needed for the sake of the intended." His career has been well documented, 
from its beginnings at the Cummington School in Massachusetts, to The University of Iowa Typographic Laboratory, the University of Nebraska (where the Cummington imprint was temporarily suspended, as Abattoir editions was born) and the resumption of Cummington upon his retirement from academic life.

The most recent Cummington publications, both books of poetry, are Twenty-Four Bagatelles in an Antique Mode (1989) by Harold Grier McCurdy, published in wrappers in a nonadhesive binding, and Breckenridge County Suite (1989) by Joe Bolton, case-bound in cloth with marbled paper sides.

\section{HERMETIC PRESS (Minneapolis, Minnesota)}

Poet, concept artist, typographer and printer Philip Gallo began his career in 1965 at The University of Iowa as a member of the Iowa Writers' Workshop and as a student of Harry Duncan at the Typographic Laboratory. For nearly twenty-five years his Hermetic Press has turned out works of great style and imagination, finding their place most comfortably within the realms of concrete and visual poetry. His work is characterized by a highly integrated sense of experimentation within very formal traditions, and is always notable for its high level of craftsmanship.

not quite semiotiks, po:ems 1987-88 (1988) consists of seven individually printed pieces, poems by Gallo comprising works found, overheard and doodled. Within them, there is much diversity in literary content, materials used, and design styles. Philip brings many skills to his work, and perhaps it is his background in advertising typography which in part makes him so effective with the short poem-particularly when given a "concrete" treatment. 
During 1988-89 Gallo designed and printed two book-length works for Granary Books in New York City: Aposiopeses by Jonathan Williams and from The Book of Legends, a first book by Jane Brakhage.

\section{LABYRINTH EDITIONS (Lincoln, Nebraska/Honolulu, Hawaii)}

In 1974, poet/printer/designer and teacher Richard Bigus was a student at Cowell College in Santa Cruz, studying with William Everson and producing broadsides of his own concrete poetry. While in California he also studied with Jack Stauffacher, and in 1975 went on to study graphic art at Yale. In recent years Richard has taught at universities in Ohio, Iowa, Nebraska, and New Zealand, and is now living and teaching in Hawaii.

His early works are largely experiments in concrete typography, culminating in the highly unusual and dramatic rendering of Whitman's Out of the Cradle Endlessly Rocking (1978). He has published several fine editions of works by Auden, Rexroth and others, often making use of vellum, and in 1984 wrote and printed a beautiful treatise on the art of printing on that material, called The Mystique of Vellum, published by Bromer Booksellers. Labyrinth's most recent publication is Her Six Difficulties and His Small Mistakes (1988), poems by Marcia Southwick, illustrated with eight relief prints by the printer.

\section{PENUMBRA PRESS (Omaha, Nebraska)}

Bonnie O'Connell's career as a publisher of literature and graphics began in 1968 with Under Heaven by William Terrill - eight poems handprinted in an edition of thirty copies and issued under the Cynthia Press imprint while she was an undergraduate at the University of Wisconsin, Madison. This book was followed by The Abyss by Dan Rose (1969) before the Press moved, first to Urbana, Illinois, and then to Lisbon, Iowa. With her third book, Little Notes to You, From Lucas Street (1972), a book of poems by Kathleen Fraser, Bonnie adopted a new name - the Penumbra Press. One of the finest books from the Press is Cartography (1980), a book of poems by Deborah 
Greger, which shows Bonnie's vibrant use of color and texture. The title page is illustrated with a six-color relief print by the printer, who also designed and bound the edition.

In 1986 the Penumbra Press moved again, this time from the farm outside Lisbon, Iowa, to Omaha, Nebraska, where Bonnie accepted the directorship of Abattoir Editions, and teaches in the book arts program at the University of Nebraska. Since 1986 three publications have been issued with a joint Penumbra/ Abattoir imprint.

\section{THE PERISHABLE PRESS (Mt. Horeb, Wisconsin)}

Now in its third decade of service from rural Wisconsin, Walter Hamady's Perishable Press continues to produce some of the most distinctive books of our time. In its tenure the Press has published over one hundred books, with an emphasis on vital writing by some of America's most energetic poets: Paul Blackburn, Robert Duncan, Denise Levertov, Robert Creeley, and Joel Oppenheimer, to name but a few.

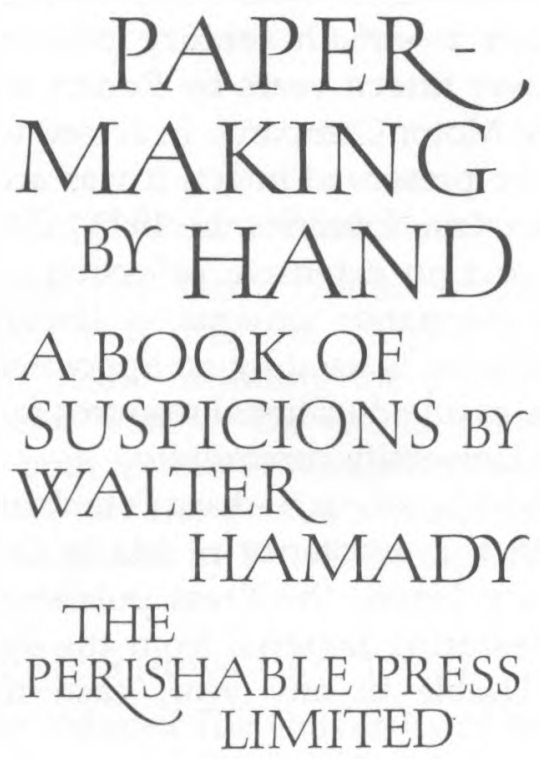


Though it is difficult to choose representative examples from among his diverse publications, one of our favorites is Papermaking By Hand: A Book of Suspicions (1982), containing Hamady's view of the craft. Printed on thirteen of his own various Shadwell papers along with half a dozen others from around the world, with a four-color titlepage pen-crafted by Hermann Zapf, and a binding by William Anthony \& Associates, it is a very fulfilling volume.

Also astonishing is the most recent book from the press, Neopostmodernism or Dieser Rasen Ist Kein Hundeklo or Gabberjab Number 6 (1989). A virtuosic tour de force through dozens of printing (and non-printing) processes, many of which have been newly envisioned in these applications, on various papers and hospital cloth, in several languages and featuring a number of extraordinary occurences, it is the sixth in Hamady's series of books which playfully parody the conventions of the fine press book.

\section{SILVER BUCKLE PRESS (Madison, Wisconsin)}

The Silver Buckle Press began with a superb collection of late nineteenth and early twentieth century printing equipment brought together over fifteen years by Robert Shaftoe, an art director for the Ford Motor Company. In accord with his desire that the collection be preserved intact, it was acquired by the University of Wisconsin Libraries in 1973. Consisting of a variety of presses and an extensive collection of wood type, display faces and decorative ornaments (most in excellent condition), the collection is used by an appointed Printer and staff, and functions as an educational resource for groups both in and outside the University community.

The current Printer/Curator is Barbara Tetenbaum; under her direction, and with the assistance of Marta Gomez, Phyllis McGibbon and Tracy Honn, the Press published a Universal Calendar in 1988, featuring material from the Printer's Ornament Collection. Usable in any year, each month of the 
calendar is delightfully illustrated by a full-page typographic composition printed in as many as three colors.

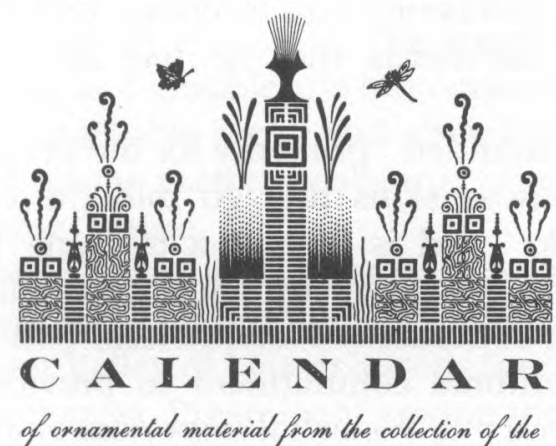

SILVER BUCKLE PRESS

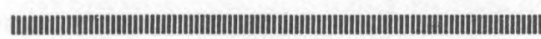

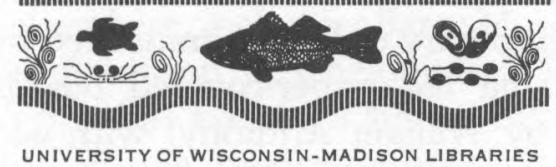

MADISON, WISCONSIN U.S.A. 1988

\section{TIRAMISU PRESS (Madison, Wisconsin)}

The books published by Marta Gomez under the Tiramisu imprint have been rich and yet elegant presentations of thought-provoking texts, including the passionate poems of Peruvian poet Cesar Vallejo. On Second Thought (1987) and Carpe Diem (1989) both feature philosophical texts by Ivan Soll, printed expressively on the printer's handmade paper, and illustrated with lithographs by Phyllis McGibbon, printed from the stones by the artist.

\section{WINDHOVER PRESS (Iowa City, Iowa)}

When Kim Merker induced The University of Iowa to establish the Windhover Press in 1967, he already had ten years of 
experience printing much-admired books under his Stone Wall Press imprint. He had first arrived at the University as a student in 1956, the same year that Harry Duncan became the director of the Typographic Laboratory, and it was Duncan's example, through publishing and teaching, that both inspired him and set the standards that he has since consistently fulfilled.

Windhover was founded "primarily for the preservation and dissemination of those skills that go into the creating of a hand-printed book," and is in part a teaching press where students are able to work directly with Merker in the design and execution of publications. Nonetheless, both presses observe the same editorial commitment to previously unpublished work of literary or historical importance, and the same high standards of design and craftsmanship.

If I Were Fire (1987) features thirty-four sonnets of Cecco Angiolieri, a contemporary of Dante, translated by Felix Stefanile. Bound in flame red paper-covered boards in a nonadhesive binding by William Anthony, with each title page individually calligraphed by Glen Epstein, it is a perfect example of Windhover's ability to combine worthy texts and fine handcraft.

\section{YELLOW BARN PRESS (Council Bluffs, Iowa)}

1979 marked the year of the first publication of Neil Shaver's Yellow Barn Press. Many volumes of poetry, essays and biography have issued hence since, frequently graced with illustrations by wood engraver John DePol. In 1988 the Press issued A Goudy Memoir: Essays by and about America's Great Type Designer. The essays are set in a variety of faces designed by Goudy and are nicely illustrated with tipped-in photographs from diverse sources, and wood engravings by John DePol.

In the Midwest there are currently numerous other fine presses, among them: Adagio Press; Buttonmaker Press; 
Iguana Press; Logan Elm Press; Midnight Paper Sales; Pentagram Press; Pterodactyl Press; Seamark Press; and Vestige Press.

\section{EAST and SOUTH}

Whether in spite of, or thanks to, the concentration of commercial publishing and graphic arts industries in the East, there is at present a remarkable range and abundance of handwork being produced on the eastern seaboard, from Winter Haven, Florida, to Bangor, Maine.

Two geographical areas within the East deserve special note for their extraordinary concentration of significant activity. The first is the Pioneer Valley of Massachusetts (generally speaking, the Northampton area). Preeminent among the artists working there is Leonard Baskin at the Gehenna Press, whose masterful printing and illustration have inspired many other fine presses in the area and elsewhere, including Barry Moser at Pennyroyal and Alan James Robinson at Cheloniidae. The presence of binder Arno Werner has exerted a similar influence, resulting in a community of fine binders whose concentration and quality is unsurpassed in the country. Among the more prominent of these would be Gray Parrot (now working in Maine), Donald Glaister, Daniel Kelm, Sarah Pringle, Claudia Cohen, David Bourbeau, Sarah Creighton and Peter Geraty. Other concerns active in the Pioneer Valley include Catawba Press, Wild Carrot Letterpress, Golgonooza Letterfoundry, Warwick Press, the calligrapher Suzanne Moore, and no doubt others.

The other area requiring particular mention is New York City. As in everything else, the City fosters an intensity and diversity of book-related activity that is difficult to encompass. Supporting the full range of book arts in New York are numerous institutions, who through their collections, exhibitions, courses and promotion help maintain the high pitch of activity and interest: the Center for Book Arts, founded in 1974 by binder Richard Minsky; the New York Public Library; the Grolier Club; the Typophiles; the School of Library Services at Columbia University; the Whitney Museum; the Watson Li- 
brary of the Metropolitan Museum of Art; Dieu Donne papermill; and Franklin Furnace, among others.

There is also a strong interface between the visual art establishment in New York and many makers of fine books. Among the many publishers who are thus engaged, with roots variously in either domain, are Petersburg Press, Vincent Fitz Gerald, Kaldewey Press, Solo, the reconstituted Limited Editions Club, Pace Editions, Grenfell Press, and the Library Fellows of the Whitney Museum of American Art.

Special note should also be made of a number of organizations located throughout the East engaged in supporting and promoting artists' books, with an emphasis in some cases on offset and photographic processes: Nexus Press in Atlanta, Georgia; Pyramid Atlantic in Washington, D.C.; Visual Studies Workshop in Rochester, New York; the Center for Editions at the State University of New York at Purchase; Women's Studio Workshop in Rosendale, New York; and Printed Matter in New York City.

\section{ANACHRONIC EDITIONS (Winter Haven, Florida)}

Steven and Meryl Chayt are the editors and publishers of Anachronic Editions. In 1983 they issued Collotype: Being a History-Practicum-Bibliography, a definitive history of the collotype process. The success of that book has been repeated in their current title, A Ludlow Anthology (1986), which is as informative as it is beautiful. It is a compilation of articles which taken together argue the usefulness of the Ludlow Typograph as a major means of providing typographical material for the private press printer. Six of these (including three by Douglas McMurtrie) first appeared as booklets published by Ludlow; these have been supplemented by two additional articles, an updated history of the machine, a bibliography, an index of Ludlow faces and their designers, and a list of suppliers. 
Stunningly designed and set by hand entirely on the Ludlow, each section of the book is typographically distinct and lavishly illustrated in many colors.

\section{BIRD \& BULL PRESS (Newtown, Pennsylvania)}

Since 1958 Henry Morris has been publishing significant works emphasizing topics pertaining to the traditional arts of the book. The contribution of Bird \& Bull in this context is perhaps unequalled. Among the numerous worthwhile books on papermaking, for instance, are Timothy Barrett's Nagashizuki: The Japanese Craft of Hand Papermaking (1979) and A Pair on Paper: Two Essays on Paper History and Related Matters (1976) by Leonard B. Schlosser and Henry Morris. 1988 saw the publication of Thirty Years of Bird \& Bull: A Bibliography compiled by Howell J. Heaney with a foreword and commentary by Morris. Each copy in the edition of 300 is accompanied by a generous portfolio of assorted ephemeral material.

\section{TIMOTHY C. ELY (New York, New York)}

Timothy Ely's one-of-a-kind artists' books are aimed toward "the whole (holistic) book." His concerns are equally with the richly drawn, written and painted pages as with the structure and execution of the binding or package; his books function simultaneously as works of art, carriers of information, and focusing devices for esoteric experience. With a background in painting, and studies with English binder Philip Smith, Tim brings a wonderful sense of technical skill, imagination and possibility to the making of books. His collaboration with Ruth Lingen at the Poote Press (Brooklyn, New York) on Joe Napora's SCIGHTE (1987) is a beautifully integrated work fusing Napora's text, Tim's magnesium linecut illustrations, and Lingen's pulp paintings, with a binding designed and executed by Tim as well.

\section{VINCENT FITZ GERALD (New York, New York)}

Vincent Fitz Gerald is a New York City art dealer who began publishing books in 1981. His first publication, entitled The Story of the Merchant and the Parrot, was an interpretive transla- 
tion of the thirteenth century Sufi poet Rumi by Zahra Partovi. The edition was illustrated by Don Kunz, printed letterpress at the Kelly/Winterton Press, and bound by Gerard Charriere. Vincent's guiding hand in the editing and design of his publications is clear, despite the fact that most of the production work is accomplished through various independent artists.

In 1987 the press published The Epiphanies of James Joyce. These forty "epiphanies" were written at various times when Joyce was between the ages of eighteen and twenty-one, and though a few became the basis for sections of Dubliners and Ulysses, the complete group is published here for the first time. An ambitious and compelling work, it features sixty-four remarkable visual images by Susan Weil and Marjorie van Dyke, employing hand coloration and original collage. With calligraphy by Jerry Kelly, typecasting by Golgonooza Letterfoundry, letterpress printing by the Wild Carrot Letterpress, and a box housing the book by David Borbeau of the Thistle Bindery, it is a very striking and engaging production.

\section{GRENFELL PRESS (New York, New York)}

The Grenfell Press began in 1980 with the publication of Typefaces \& $c_{\text {., }}$ a volume of poetry and drawings by contemporary writers and artists, which displayed the range of typefaces then available at the Press. In its thirty-two pages, eight colors, and various illustrative processes it also intimated the range of interests and sensibilities that have been employed in the dozen books that Leslie Miller, the proprietor, has issued since. Artist/writer collaborations are a hallmark of the Press, which places itself in the editorial tradition of the Hours Press, Seizin Press and Three Mountains. Among the always noteworthy pairings have been William Burroughs and Brion Gysin, Robert Duncan and R.B. Kitaj, Peter Cole and Joel Shapiro, and Harry Mathews and Trevor Winkfield. Most recently Leslie has published a second book by author Mathews, Singular Pleasures 
(1988). In it more than one hundred prose vignettes are interwoven with sixty-five duotone lithographs by Francesco Clemente.

\section{JANUS PRESS (West Burke, Vermont)}

The output of Claire Van Vliet's remarkable Janus Press over the last thirty-four years has been the subject of several exhibitions and accompanying bibliographic catalogues. Her books have typically featured significant texts accompanied by powerful illustrations, in many cases by Claire herself, whose highly-respected visual work in various media (drawing, watercolor, wood engraving, intaglio, lithography, among others) is inseparable from her work as a bookmaker. In recent years she has also been immersed in papermaking, and has created striking "paperworks," pulp-paper paintings that stand alone or are incorporated into printed books.

Both of Claire's most recent books are highly integrated innovations. Aunt Sallie's Lament (1988) by Margaret Kaufman features a poem relating the life and lost love of a quiltmaker, printed on handmade paper in numerous colors. Its ingenious binding structure features variously shaped pages, each containing a stanza of the poem, which unfold to create a "quilted" diamond composition; at the end, all of the terminal lines of the stanzas can still be read. Dido and Aeneas (1989), co-published with Michael Alpert at the Theodore Press, is an accordionfolded handmade pulp-paper sequence that unfolds to six feet in length. It is a 300th anniversary publication of Nahum Tate's libretto for the opera by Henry Purcell. Bound into each pictorial spread (some of which also have added collage elements) are pamphlets bearing the text. The whole when unfolded becomes a miniature theater.

The Theodore Press is also the publisher of a magnificent edition of King Lear (1986), based on the first folio text, illustrated with thirty-nine woodcuts by Claire, printed by her directly from the blocks, on handmade paper. She also de- 
signed the binding, which uses birch boards decorated with black and white ink and a tawed pigskin spine.

\section{KALDEWEY PRESS (Poestenkill, New York)}

Gunnar Kaldewey's stated aim is to "find new ways of creating illustrated books" employing "both the traditional and the most modern techniques of book production." The Press is dedicated to presenting contemporary texts in their original language; both the contents and the materials of his books come from all over the world. Gunnar established his press in Germany, after many years of experience in the rare book field, and it is now housed in the Hudson Valley of New York.

Books done in collaboration with authors and artists have included texts by Samuel Beckett, Paul Celan, William Burroughs, Marguerite Duras, John Ashbery and others. In Poemas Rumantschas (1987), three poems in the Raetoromantsch language (including one by Pier Paolo Pasolini) have been illustrated by Swiss artist Not Vital, who has used black tape, pigment, tears in the paper, and included a hinged metal sawblade. The Press has also issued several books written, illustrated and printed by Kaldewey himself.

Printed on papers made exclusively for the Press, and bound, often innovatively, by fine binders in Europe and the United States, Kaldewey's books are strikingly original. In the words of Eleanor Garvey, curator of the Printing and Graphic Arts collection of the Houghton Library, writing in the introduction to the catalogue of a show of Kaldewey's books at the Watson Library of the Metropolitan Museum of Art in 1988, they are "not the livre de peintre of fifty years ago brought up to date, but a challenging expression with new materials and forms."

\section{DANIEL E. KELM (Easthampton, Massachusetts)}

Daniel Kelm's interpretive bindings are possessed of great emotional and intellectual strength, and his structures combine breathtaking craftsmanship with profound philosophical justification for forms. In his 1987 interpretation of Thistles and Thorns (published by Abattoir Editions in 1977), the approach to 
the book, through the three successive sections of his folding box, is as carefully considered and executed as the cast-paper sculpture inset into the front cover of the full leather binding.

Many of Daniel's current efforts in bookmaking are guided by, and constitute parts of, a large-scale endeavor called Project Alchemy. With a background in chemistry and philosophy he is investigating some of the implications for the present of those early "makers," the alchemists, whose works have been maligned and misconstrued throughout much of the modern period. Daniel has produced several variable, sculptural bookstructures which require the active participation of the viewer in order for their meanings to become manifest. Decorated with text and other imagery by himself, and in some cases in collaboration with Timothy Ely, these books (the Earth series, Platonic Versus, and Turning to Face) take the essential features of the physical act of reading and utilize them to allow us to wander into less-explored territories of human experience.

\section{NADJA (New York, New York)}

Doug Wolf and Carol Sturm at Nadja have been producing important works of contemporary poetry for over ten years. A restrained typographic style and a light touch with color lend their books a subtle but vivid character. Authors they have published include Guy Davenport, Ezra Pound, James Merrill and W.S. Merwin; two recent, interesting books by W.D. Snodgrass have been illustrated by the artist DeLoss McGraw. Their current publication is At The Barriers (1989), a long poem by Thom Gunn, illustrated with a two-color geometric print, by the printers, on the cover and the title page.

\section{OSBORNBOOK (Arlington, Virginia)}

Kevin Osborn's artists' books combine unusual and innovative structures with virtuoso offset printing, arriving at unique and often fantastic reading experiences. Wide Open (1985) is composed of pages of drawings printed offset using lightfast inks, bound by brass rods into a wooden spine with hinged wood and plexiglass covers. It is a large book that functions equally as a sculpture, complete with its own stand. A more 
recent example is Tropos (1988), a $61 / 2^{\prime \prime}$ x $8^{\prime \prime}$ parallelogram, printed using thirty-seven metallic, translucent and opaque inks in multiple overlays, bound in a $11 / 4$ " raw wood spine. The display version is mounted on a $44^{\prime \prime}$ inclined wooden strut (an extension of the spine) with a wooden base.

\section{PURGATORY PIE PRESS (New York, New York)}

Esther K. Smith and Dikko Faust operate the Purgatory Pie Press from a historic cast-iron building on Broadway, in Soho, New York City. Producing a wide range of innovative and idiosyncratic printed material (from books and postcards to leather-bound eccentrically shaped datebooks), Purgatory Pie is very much a collaborative press. Artists and writers are involved with Smith and Faust in the organic process of bookmaking. This is sharply in evidence in their annual subscription series of postcards (now in its eighth year), which combines the talents of artist, designer, writer and printer in a most lively and creative fashion. A good sense of humor, translated with integrity into often surprising materials and techniques, typically characterizes the publications of this noteworthy press.

\section{RED OZIER PRESS (New York, New York)}

Aficionados of finely made literary books will undoubtedly be familiar with the work of the Red Ozier Press. In the more than twelve year history of the Press, Steve Miller and Ken Botnick published a diverse selection of contemporary writing, including Russell Edson, Robert Bly, William Burroughs, Charles Wright, Octavio Paz, William Bronk, and many others. In 1983 the Press undertook its most ambitious project: Father Abraham by William Faulkner, illustrated with wood engravings by John DePol. Among the most stunningly designed books of the Press was The Bicycle Rider by Guy Davenport (1985). With its Mondrian-influenced four-color title page, wrappers of Dieu Donne handmade paper and striking use of Futura and Spectrum types this work takes many risks and achieves expert results. 
Having left its New York City home of nearly ten years in 1988, Red Ozier was formally dissolved in 1989. Steve Miller is currently teaching at the University of Alabama's Book Arts Program in Tuscaloosa and publishing privately under the Red Hydra imprint. Two works have been issued to date: a broadside poem by Olga Broumas, Mercy (1989), with a woodcut by Antonio Frasconi, and a book by Thom Gunn, Death's Door (1989). Ken Botnick lives in Woodbridge, Connecticut, and works as a designer for Yale University Press. He published this year a broadside featuring a poem by Octavio Paz, printed in both the original Spanish and an English translation by Eliot Weinberger, accompanied by a remarkable photogravure, from a photograph by Nina Subin; he presently has several interesting projects in the works.

\section{TATLIN BOOKS/LANDLOCKED PRESS (Bangor, Maine)}

After a move from Madison, Wisconsin, to Bangor, Maine, Walter Tisdale's Landlocked Press has become Tatlin Books. Noting his studies with Walter Hamdy at the University of Wisconsin and his collaborations with Katherine Kuehn of the Salient Seedling Press (now in New York City), one could have predicted that Walter Tisdale's books would be expertly crafted, and they certainly have been. An inventive typographer and astute editor, Walter is principally responsible for all aspects of his publishing: editing, design, printing and binding. The Weather Within (1985) by Theodore Enslin is subtly printed in four colors and nicely illustrated with drawings by Kim Wilson. Currently on the press is a new translation, by Karl Young, of the Anglo-Saxon poem The Seafarer.

\section{WARWICK PRESS (Easthampton, Massachusetts)}

Since 1973 Carol J. Blinn's Warwick Press has produced a fine body of work, ranging from the whimsical A Poultry Piece: Being a Discourse on the Joys of Raising Ducks and Geese (1978) to the serious Arno Werner: One Man's Work (1982), edited and introduced by Carol. The main body of this latter book consists of the text of a lecture delivered by Arno Werner at Harvard 
University on the occasion of his first one-man exhibition of hand bookbinding. Designed, illustrated and printed by Carol Blinn, the volume was bound in half leather by Carol and Arno. In 1988, Carol designed, set, printed, decorated and bound Out West, A Poem in Paste in an edition of thirty copies. At the heart of this book is a poem printed directly onto a pastepaper painting, each of which is a response by the printer to the experience of the dramatic open space of the American West.

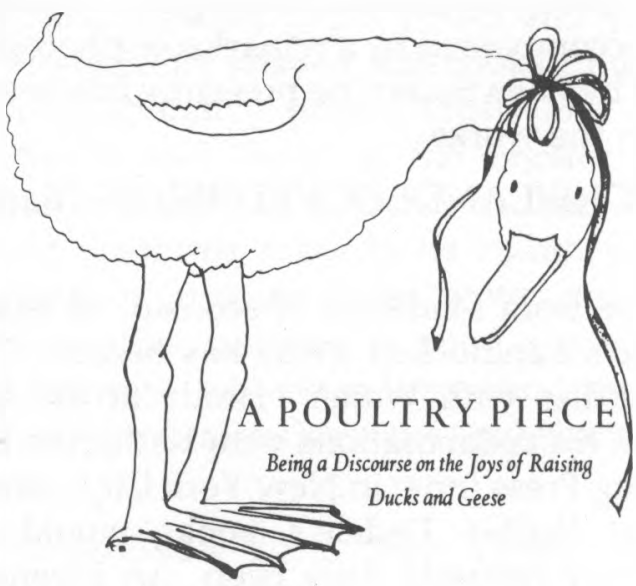

WRITTEN \& ILLUSTRATED BY CAROL J. BLINN

WARWICK PRESS - EASTHAMPTON

1978

WHITNEY MUSEUM OF AMERICAN ART (New York, New York)

Under the editorial direction of May Castelberry, the Library Fellows of the Whitney Museum publishes its Artists and Writers series of illustrated books. The current volume (the sixth in the series) is My Pretty Pony (1989), a previously unpublished short story by Stephen King illustrated with nine 
lithographs by Barbara Kruger. The large folio volume has been bound by Craig Jensen in leather, cloth and stainless steel; the front cover is inset with a Big Time digital timepiece. Other collaborations in the series have included Richard Tuttle and Mei-Mei Berssenbrugge, and Eric Fischl and Jamaica Kincaid, with a forthcoming project featuring George Condo and William Burroughs.

Among the very many other bookmakers active in the East are: Anvil Press; The Press of Appletree Alley; Aralia Press; Banyan Press; Blue Moon Press; John Eric Broaddus; Caliban Press; Contre Coup; Jordan Davies; Doe Press; Ear/Say; Emanon Press; Eremite Press; Ric Haynes; Isolde Press; Earl Kallemeyn; Kelly/Winterton; King Library Press; Married Mettle Press; (the) Moonkosh Press; Oliphant Press; Parallel Editions; Periphery; Petrarch Press; Raven Press; Red Angel Press; Salient Seedling Press; Sarabande Press; Sea Cliff Press; Keith Smith; Stone House Press; Vehicle Editions; and Vital Signs.

It must be clear from even this cursory survey that the fine printing and bookmaking community in the U.S. continues to grow vigorously, finding new avenues through which to extend the domain of its activity, and eliciting new sources of support. This is of more than passing consolation in a time when technological opportunities seem so infrequently to address basic human needs and capacities. The book is not dead, and its life sustains our own. 